\title{
LONG TERM CORRELATION BETWEEN CANCER AND CARDIOVASCULAR DEATHS ACCORDING TO VARIOUS TRENDS IN SLOVAK DISTRICTS 1994-2003
}

\author{
Mária Letkovičová', Hana Zach ${ }^{1}$, Martin Letkovič ${ }^{1}$, Alexander Martin Čelko² \\ ${ }^{1}$ Environment a.s., Centre of Biostatistics and Environment, Nitra, Slovak Republic \\ ${ }^{2}$ Charles University in Prague, 3rd Faculty of Medicine, Center of Preventive Medicine, Epidemiology Department, Prague, Czech Republic
}

\section{SUMMARY}

The aim of the article was to point out recorded cardiovascular deaths did not copy the real number of cardiovascular deaths, but may also include other causes of deaths. We evaluated all death notifications reported to the Statistical Office of the Slovak republic during the 10-year period, that is 519,680 cases in total. We analysed the year of death, location of death and the cause of death. The causes of deaths were split into three groups: cancer deaths, cardiovascular deaths (CVD) and other deaths. We used the fuzzy c cluster analysis and the basic epidemiological and statistical methods for the evaluation. We uncovered some Slovak districts had long-term higher mortality (Lučenec, Rimavská Sobota, Rožñava, Trebišov and Krupina), as well as the other districts having the long-term lower mortality (Bratislava, Košice, almost all Žilina region, Poprad, Spišská Nová Ves and Dunajská Streda). The cancer and cardiovascular deaths significantly correlated in terms of the Slovak districts. Evaluating the mutual causes of death proportion we identified two groups of Slovak districts; the first group of districts showing higher CVD deaths had lower cancer and other deaths, the second having higher proportion of cancer and other deaths reached the lower CVD deaths. It seems deaths have the similar pattern throughout the whole country, and the numerical differences are probably given only by the quality and the quantity of the death certification.

Key words: cardiovascular deaths, cancer deaths, mortality, fuzzy sets, Slovak Republic

Address for correspondence: M. Letkovičová, Environment a. S., Dlhá 108, 94901 Nitra, Slovak Republic.

E-mail: letkovicova@environment.sk

\section{INTRODUCTION}

The aim of the article was to point out recorded cardiovascular deaths did not copy the real number of cardiovascular deaths, but may also include other causes of deaths. The study compared the trends of notified total and specific cardiovascular deaths and showed cardiovascular deaths did not represent the real cardiovascular deaths themselves but differentially represented also other causes of deaths.

\section{MATERIAL AND METHODS}

The study was based on the anonymous dataset of individual deaths certificates recorded by the Statistical Office of the Slovak Republic in 1994-2003. In 1994-2003 519,680 death cases were reported to the Statistical Office of the Slovak Republic (1).

The death cases were split into three groups:

- cardiovascular deaths (coded as I00-I99 according to ICD 10) - abbreviated as CVD,

- cancer deaths (coded as C00-C97 according to ICD 10)abbreviated as $\mathrm{Ca}$,

- other deaths - abbreviated as other.

Calculated proportions of death cases were as follows: $55 \%$ of all deaths were due to cardiovascular causes, $22 \%$ of all deaths were caused by cancer causes and $23 \%$ of all deaths were due to other causes (Fig. 1). Calculated figures were not adjusted for changes in the Slovak population because there were not substantial changes in composition of the Slovak population in studied period.

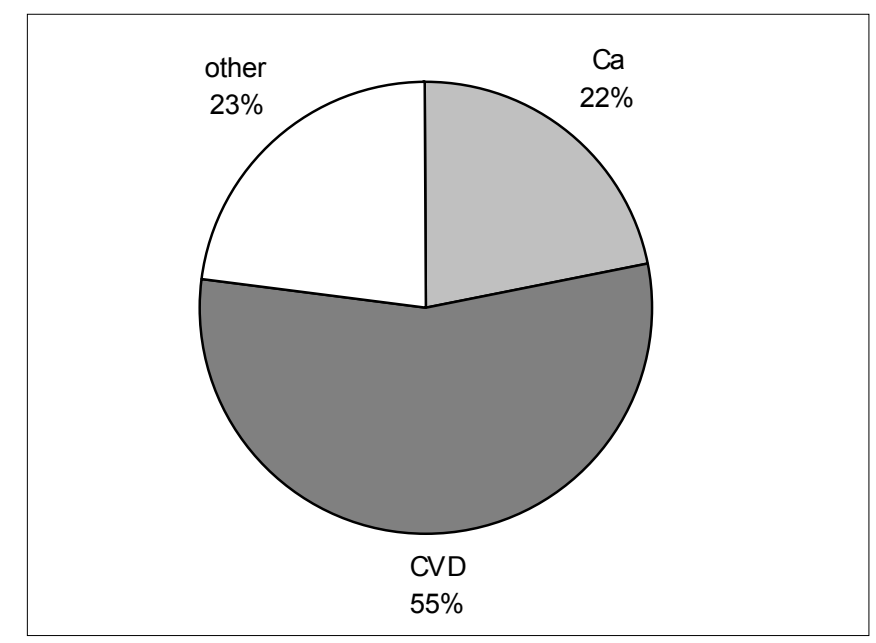

Source: own calculations

Fig. 1. Cause specific proportions of all deaths in Slovakia in 1994-2003. 
Table 1. Cause specific death rate in Slovak districts in 1994-2003

\begin{tabular}{|l|c|c|c|c|}
\hline \multirow{2}{*}{ District } & \multicolumn{3}{|c|}{ Proportion of causes of death (\%) } & \multirow{2}{*}{$\begin{array}{c}\text { Extreme } \\
\text { observation }\end{array}$} \\
\cline { 2 - 4 } & Ca & CVD & other & \\
\hline Snina & 18 & 66 & 16 & max CVD \\
\hline Dolný Kubín & 23 & 49 & 28 & low CVD \\
\hline Nitra & 25 & 51 & 24 & max Ca \\
\hline Krupina & 17 & 62 & 21 & low Ca \\
\hline Zvolen & 20 & 49 & 31 & high other \\
\hline Snina & 18 & 66 & 16 & low other \\
\hline
\end{tabular}

Source: own calculations

Long-term trend evaluations by the Slovak districts showed substantial ranges of values:

- proportion of cardiovascular deaths varied between $49-66 \%$,

- proportion of cancer deaths varied between $17-25 \%$,

- proportion of other deaths varied between 16-31\%.

Extreme observations within 79 Slovak districts were obtained comparing calculated proportions of cause specific death rate (Table 1).

The role of the fuzzy $c$ cluster analysis in our article was to allocate 79 Slovak districts into clusters having the highest internal homogeneity as well as to reach the highest inter cluster differences. Membership to each cluster was defined by standard that was minimal, that means the object distance from the cluster centroid $t$ was minimal. The main advantage of the fuzzy $c$ cluster analysis was the possibility to evaluate non-normal data and to create defined and undefined clusters. Fuzzy $c$ cluster analysis was the suitable statistical method for clustering of objects (Slovak districts) having similar progress during $p$ period ( $p=1994-2003$ ) in terms of evaluated variables (CVD, Ca and other deaths) $(2,3)$. If we mark $O=\left(z_{l}, z_{2}, \ldots, z_{n}\right) n$ objects $\left(z_{k}=\right.$ particular Slovak district; $n=79$ Slovak districts) with the membership function values $a z_{1}, a z_{2}, \ldots, a z_{n}\left(a z_{k}=\right.$ membership function for the particular Slovak district), then the fuzzy $c$ partition of $O$ objects was defined as a subset system $q=\left(p_{l}, p_{2}, \ldots, p_{c}\right)$, where for all $x_{k}$ $(k=1,2, \ldots, n)\left(x_{k}=\mathrm{CVD}, \mathrm{Ca}\right.$ or other deaths) refered [1]

$$
\sum_{i=1}^{c} p_{i}\left(z_{k}\right)=1
$$

where $p_{i}\left(z_{k}\right)$ was a membership function value $p_{i}(i=1,2, \ldots$, $c)$ of object $z_{k}(k=1,2, \ldots, n)$. $t_{i}[2]$

The partition $q=\left(p_{1}, p_{2}, \ldots, p_{c}\right)$ approved the clusters centroids

$$
t_{i}=\frac{\sum_{k=1}^{n}\left[p i\left(z_{k}\right)\right]^{m} x_{k}}{\sum^{n}\left[p_{i}\left(z_{k}\right)\right]^{m}}
$$

where $m>1$. The object weight $z_{k}$ determinated the degree of membership into the subset $p_{i}$. The partition quality $q$ as well as the optimal number of clusters was defined according to the coefficient of separation $\left[p_{i}\left(z_{k}\right) \geq 0,8\right]$. SYN-TAX-pc software was used for the calculations (4). Final maps were depicted using the Arc View software.

\section{RESULTS}

Following facts were observed evaluating the death causes in districts using the fuzzy sets.

1. The cause specific death rate per 100,000 inhabitants - all deaths in 10-year period divided by the sum of inhabitants over the 10-year period.

The fuzzy $c$ cluster analysis resulted in two different clusters of the Slovak districts. The first cluster indicated the long-term higher mortality proportions in all groups of deaths; the CVD mortality was considerably higher (Fig. 2).

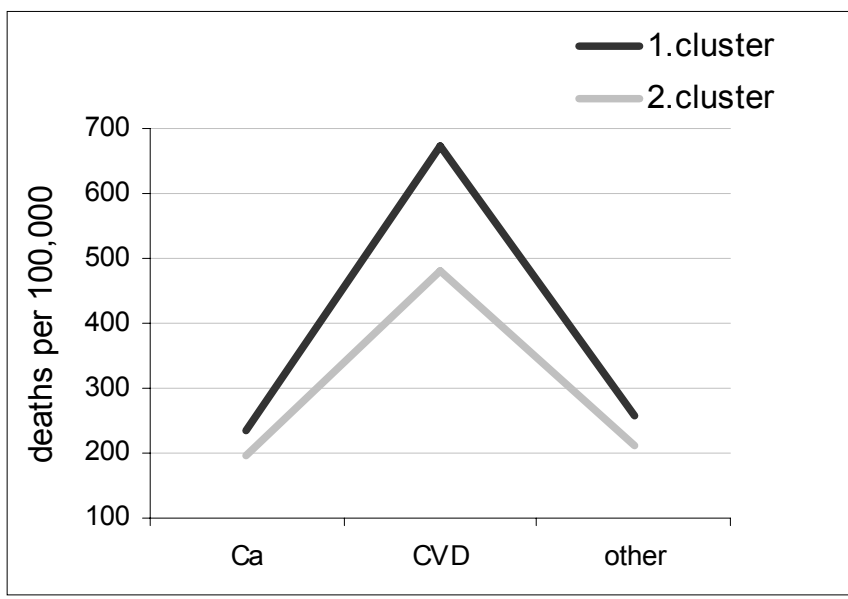

Source: own calculations

Fig. 2. Slovak districts according to 10-year cause specific death rate per 100,000 inhabitants.

The proportions in both clusters were as follows:

- Ca deaths in the first cluster were 1,2 times higher than in the second cluster,

- CVD deaths in the first cluster were 1,4 times higher than in the second cluster,

- other deaths in the first cluster were 1,2 times higher than in the second cluster.

Figure 3 displayed the district clustering. The Slovak districts reaching the higher deaths proportions, no matter the cause of death (but mainly CVD deaths) were located on the south of the Slovak Republic.

2. The cause specific death rate in percentage-percentage of deaths on particular cause.

The fuzzy $c$ cluster analysis resulted in two different clusters of the Slovak districts. The first cluster indicated the long-term lower percentage of $\mathrm{Ca}$ and other deaths, but considerably higher CVD deaths. The second cluster showed the long-term lower proportion of CVD deaths, but higher proportion of $\mathrm{Ca}$ and other deaths (Fig. 4). 


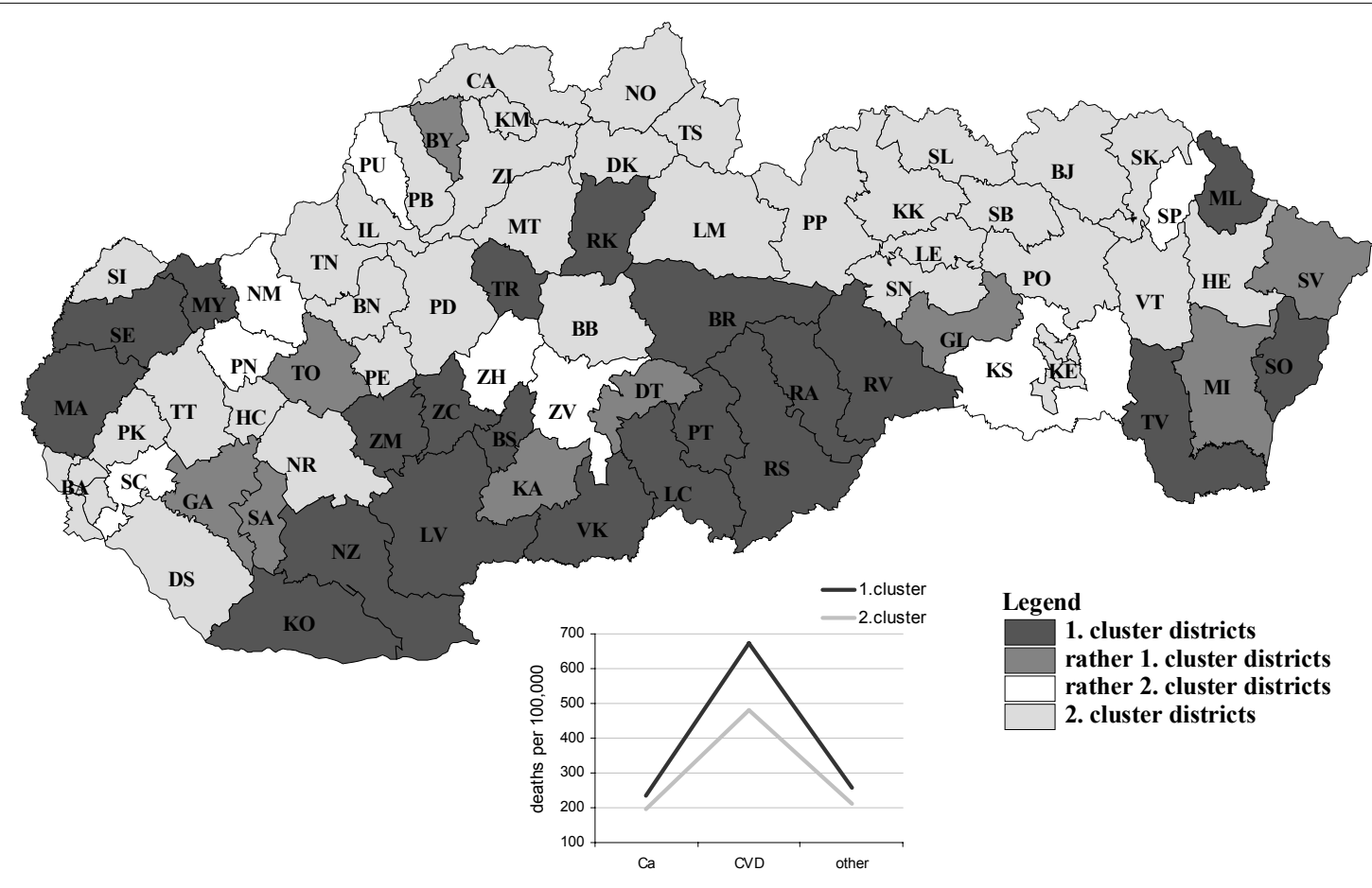

Source: own calculations. For abbreviations see Table 2.

Fig. 3. Long-term mortality in the Slovak republic, 1994-2003.

Cause specific death rate (number of deaths on 100,000 inhabitants in person years).

The proportions in both clusters were as follows:

- proportion of $\mathrm{Ca}$ deaths in the first cluster was 0,9 times lower than in the second cluster,

- proportion of CVD deaths in the first cluster was 1,1 times higher than in the second cluster,

- proportion of other deaths in the first cluster was 0,8 times lower than in the second cluster.

The result signalled the deformity in the mortality pattern. In districts reporting lower $\mathrm{Ca}$ and other deaths the CVD deaths considerably exceeded. We supposed the districts of the first cluster

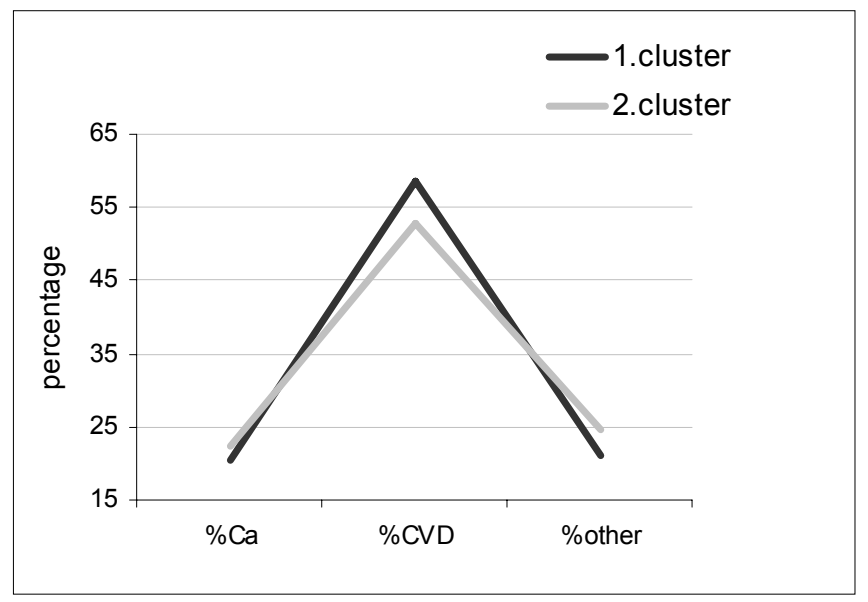

Source: own calculations

Fig. 4. Slovak districts according to 10-year cause specific death rate in percentage. reaching higher CVD deaths were not actually "unhealthy", the problem should be seen in insufficient death notification differentiation. District clustering was depicted on Fig. 5.

3. Merging both previous calculations and denomination of extreme districts.

Finally, we merged both calculations into one Figure (Fig. 6). Districts performing worse in terms of higher cardiovascular mortality in both previous fuzzy calculations were depicted in dark grey; we considered those districts for districts with bad situation in CVD mortality in reality. Districts performing better in terms of lower cardiovascular mortality in both previous calculations were depicted in light grey, and their situation is considered good in reality as well. Undefined districts or fuzzy status was depicted in white. Dark grey Slovak districts indicated areas with higher mortality in all death causes where also the deformity in the mortality pattern occurred.

\section{DISCUSSION}

The article demonstrated our approach to the complex classification of geographic areas that could be a supportive tool for the decision makers. We discovered the Slovak districts depicted in dark grey had the worst mortality status. We suggest focusing the prior attention to those districts. In case of small districts the district dimension and older population can distort the results, though the calculations were performed using the 10-year sums. However, the situation in large districts on the south of Slovakia as in Lučenec, Rimavská Sobota, Rožňava (Banská Bystrica region) 


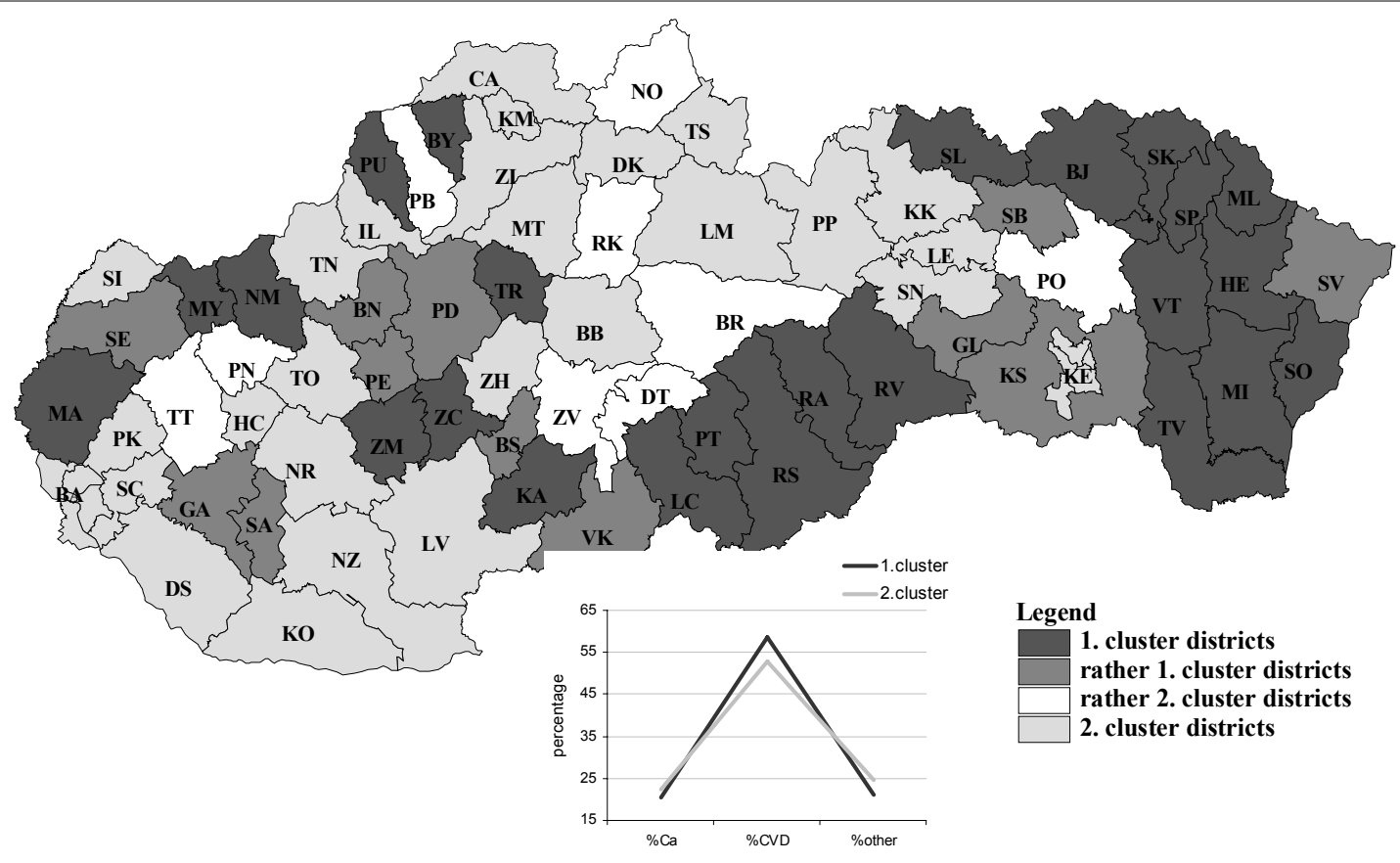

Source: own calculations. For abbreviations see Table 2.

Fig. 5. Long-term mortality in the Slovak republic, 1994-2003.

Cause specific death rate in percentage (based on number of deaths).

or Trebišov appeared to be very serious. Emergency status was in district Krupina where the worst situation occurred not only in case of the mortality $(5,6,7)$. Districts in emergency situation were marked in ellipse (Lučenec, Rimavská Sobota, Poltár, Rožňava, Revúca, Fig. 6). On the other hand, the situation in another large districts such as Bratislava and Košice, almost all of Žilina region, further Poprad, Spišská Nová Ves or Dunajská Streda is viewed as good. Districts Komárno, Nové Zámky, and Levice, usually displaying bad status, were neutral in this evaluation.

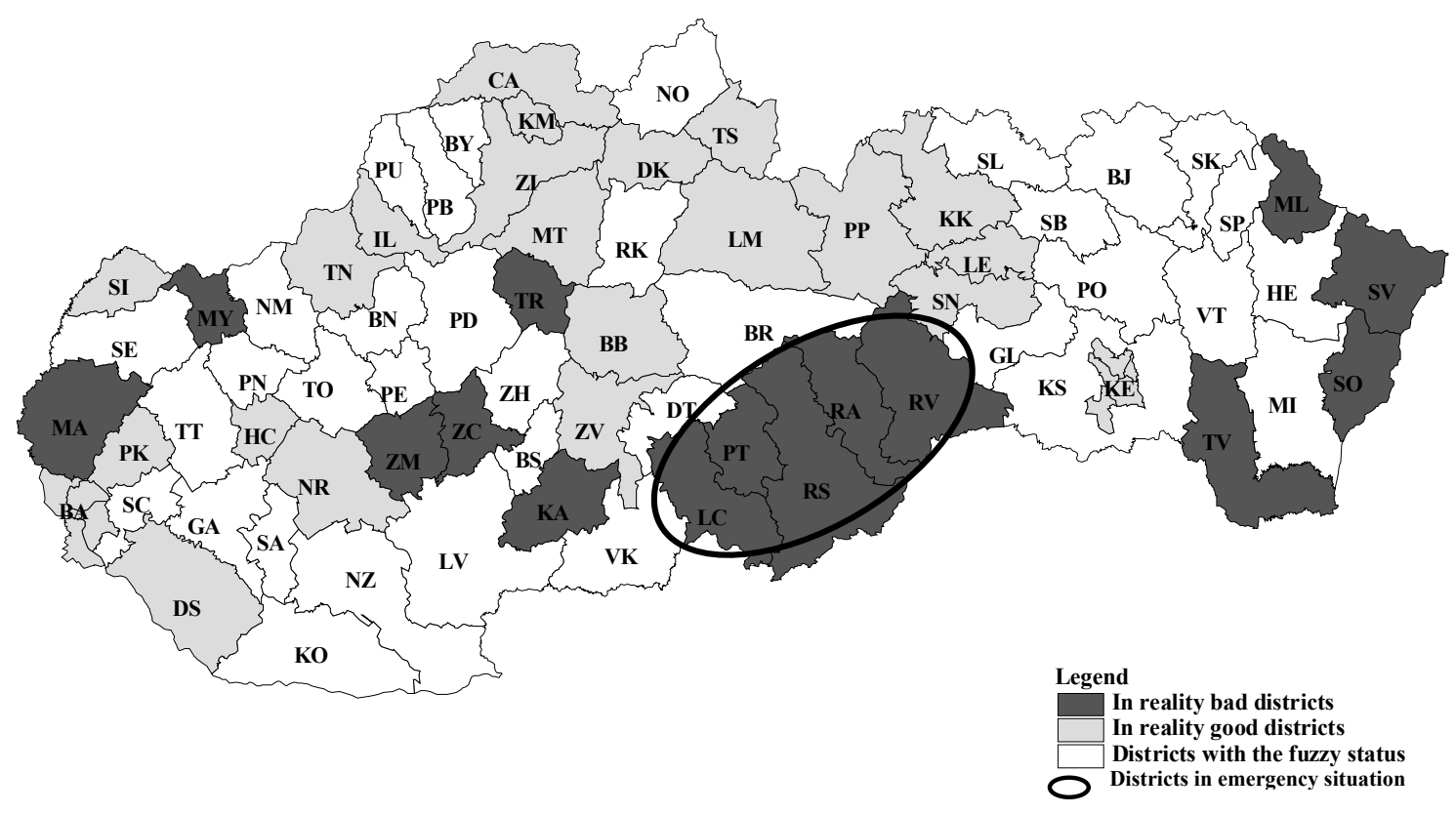

Source: own calculations. For abbreviations see Table 2.

Fig. 6. Long-term mortality in the Slovak republic, 1994-2003.

In reality bad and in reality good districts evaluated in view of the cardiovascular mortality. 
Table 2. The list of the Slovak districts abbreviations

\begin{tabular}{|c|c|c|c|c|c|c|c|c|}
\hline \multirow{2}{*}{$\frac{\text { Region }}{\text { Bratislava }}$} & \multicolumn{2}{|c|}{ District (abbreviation, name) } & \multirow{2}{*}{$\begin{array}{l}\text { Region } \\
\text { Nitra }\end{array}$} & \multicolumn{2}{|c|}{ District (abbreviation, name) } & \multirow{2}{*}{$\begin{array}{l}\text { Region } \\
\text { B.Bystrica }\end{array}$} & \multicolumn{2}{|c|}{ District (abbreviation, name) } \\
\hline & MA & Malacky & & SA & Šal'a & & ZV & Zvolen \\
\hline Bratislava & PK & Pezinok & Nitra & TO & Topol'čany & B.Bystrica & ZC & Žarnovica \\
\hline Bratislava & SC & Senec & Nitra & ZM & Zlaté Moravce & B.Bystrica & $\mathrm{ZH}$ & Žiar nad Hronom \\
\hline Bratislava & $\mathrm{BA}$ & Bratislava mesto & Žilina & BY & Bytča & Prešov & BJ & Bardejov \\
\hline Trnava & DS & Dunajská Streda & Žilina & $\mathrm{CA}$ & Čadca & Prešov & $\mathrm{HE}$ & Humenné \\
\hline Trnava & GA & Galanta & Žilina & DK & Dolný Kubín & Prešov & KK & Kežmarok \\
\hline Trnava & $\mathrm{HC}$ & Hlohovec & Žilina & KM & Kysucké Nové Mesto & Prešov & LE & Levoča \\
\hline Trnava & PN & Pieštany & Žilina & LM & Liptovský Mikuláš & Prešov & $\mathrm{ML}$ & Medzilaborce \\
\hline Trnava & SE & Senica & Žilina & MT & Martin & Prešov & $\mathrm{PP}$ & Poprad \\
\hline Trnava & SI & Skalica & Žilina & NO & Námestovo & Prešov & $\mathrm{PO}$ & Prešov \\
\hline Trnava & TT & Trnava & Žilina & RK & Ružomberok & Prešov & SB & Sabinov \\
\hline Trenčín & $\mathrm{BN}$ & Bánovce nad Bebravou & Žilina & TR & Turčianske Teplice & Prešov & SV & Snina \\
\hline Trenčín & $\mathrm{IL}$ & Ilava & Žilina & TS & Tvrdošín & Prešov & $\mathrm{SL}$ & Stará L'ubovňa \\
\hline Trenčín & MY & Myjava & Žilina & Zl & Žilina & Prešov & $\mathrm{SP}$ & Stropkov \\
\hline Trenčín & NM & Nové Mesto nad Váhom & B.Bystrica & BB & Banská Bystrica & Prešov & SK & Svidník \\
\hline Trenčín & $\mathrm{PE}$ & Partizánske & B.Bystrica & BS & Banská Štiavnica & Prešov & VT & Vranov nad Toplou \\
\hline Trenčín & PB & Považská Bystrica & B.Bystrica & BR & Brezno & Košice & $\mathrm{GL}$ & Gelnica \\
\hline Trenčín & PD & Prievidza & B.Bystrica & DT & Detva & Košice & KS & Košice-okolie \\
\hline Trenčín & $\mathrm{PU}$ & Púchov & B.Bystrica & $K A$ & Krupina & Košice & $\mathrm{Ml}$ & Michalovce \\
\hline Trenčín & TN & Trenčín & B.Bystrica & LC & Lučenec & Košice & RV & Rožňava \\
\hline Nitra & $\mathrm{KO}$ & Komárno & B.Bystrica & PT & Poltár & Košice & SO & Sobrance \\
\hline Nitra & LV & Levice & B.Bystrica & RA & Revúca & Košice & SN & Spišská Nová Ves \\
\hline Nitra & $\mathrm{NR}$ & Nitra & B.Bystrica & RS & Rimavská Sobota & Košice & TV & Trebišov \\
\hline Nitra & $\mathrm{NZ}$ & Nové Zámky & B.Bystrica & VK & Vel'ký Krtišs & Košice & KE & Kosice mesto \\
\hline
\end{tabular}

Source: Statistical Office of the Slovak republic

\section{CONCLUSION}

We supposed the cause specific death rate in the Slovak Republic, as the area of the Slovak Republic represented one small geographical formation inhabited by single race living in homogenous climate conditions and having the common life style, was stabile. Most of differences in health indicators were then due to different population structure of the population. The aim of the article was to weaken the myth of the cardiovascular deaths. The situation showed not only cardiovascular deaths caused the problem. The positive outcome should be that only $12 \%$ of the Slovak inhabitants lived in area we identified as very bad. We identified two clusters of the Slovak districts having different mortality proportions irrespective the cause of death. In cluster having higher cardiovascular deaths also the cancer and other deaths were higher (the cause specific death rate per 100,000 inhabitants - all deaths in 10-year period divided by the sum of inhabitants over the 10 -year period). We also identified two clusters of the Slovak districts where proportion of selected death causes varied. Higher cardiovascular death occurred at the expense of lower cancer and other deaths (the cause specific death rate in percentage - percentage of deaths on particular cause). We supposed the deformity in the mortality pattern was mainly due to administrative reasons. The whole part of eastern Slovakia as well as the south of Banská Bystrica region was allocated in the area of constricted mortality. Overlapping both original Figures (Figs. 3 and 5) four districts occurred in disadvantageous position
- Lučenec, Rimavská Sobota, Rožňava and Trebišov. We highly recommended focusing the prior attention to those districts. Those four districts were the most endangered in terms of future.

\section{REFERENCES}

1. Statistical Office of the Slovak Republic. Demographic Statistic: Mortality, Population [unpublished databases]. Bratislava: Statistical Office of the Slovak Republik; 1994-2004. Information Service.

2. Dunn J. A fuzzy relative of the isodata process and its use in detecting compact, well separated clusters. J Cybern. 1974;3(3):32-57.

3. Bezdek JC. Pattern recognition with fuzzy objective function algorithms. New York: Plenum Press; 1981.

4. Podani J. SYN-TAX-pc. Computer programs for multivariate data analysis in ecology and systematics. Version 5.0. User's guide. Budapest: Scientia Publishing; 1993.

5. Letkovičová M. Evaluation of the potential effect of geochemical environment on the health status of the population in Spiš-Gemer region [research report]. Nitra: Environment; 2000.

6. Letkovičová $\mathrm{M}$. The complex evaluation of environmental conditions around the NPP Mochovce for selected parameters for the year 2002 [research report]. Nitra: Environment; 2004.

7. Letkovičová M, Zach H, Príkazský V. The health status of the population neighbouring the nuclear power plants in Mochovce after 5 years of regular operation. Nitra: Environment; 2005. 